\title{
EFFECTS OF EUTROPHICATION ON SIZE AND BIOMASS OF CRUSTACEAN ZOOPLANKTON IN A TROPICAL RESERVOIR
}

\author{
PINTO-COELHO, R. M., ${ }^{1}$ BEZERRA-NETO, J. F. ${ }^{2}$ and MORAIS-JR., C. A. ${ }^{1}$ \\ ${ }^{1}$ Laboratório de Gestão de Reservatórios Tropicais, Departamento de Biologia Geral, Instituto de Ciências Biológicas, \\ Universidade Federal de Minas Gerais, Belo Horizonte, Minas Gerais, Brazil \\ ${ }^{2}$ Programa de Pós-Graduação em Ecologia, Conservação e Manejo da Vida Silvestre, Instituto de Ciências Biológicas, \\ Universidade Federal de Minas Gerais, Belo Horizonte, Minas Gerais, Brazil \\ Correspondence to: Ricardo Motta Pinto-Coelho, Laboratório de Gestão de Reservatórios Tropicais, Departamento de \\ Biologia Geral, ICB - UFMG, C.P. 486, CEP 31270-901, Belo Horizonte, \\ Minas Gerais, Brazil, e-mail: rmpc@icb.ufmg.br \\ Received November 21, 2002 - Accepted November 5, 2003 - Distributed May 31, 2005
}

(With 5 figures)

\begin{abstract}
This is a long-term study (1993-1998) on the effects of increasing eutrophication on the crustacean zooplankton structure in a eutrophic reservoir. The study first demonstrates that the eutrophication increase verified is a phenomenon well described by a single abiotic variable: total phosphorus. During the study period, zooplankton suffered extensive qualitative and quantitative changes. Significant size and biomass responses of certain zooplankton groups to the temporal variations of total phosphorus were found. These findings suggest that the variables size and biomass of major zooplankton groups should always be considered simultaneously in order to assess impacts caused by eutrophication on the structure of zooplankton.
\end{abstract}

Key words: eutrophication, reservoir, zooplankton, biomass, allometry.

\section{RESUMO}

\section{Efeitos da eutrofização sobre o tamanho e a biomassa do zooplâncton crustáceo em um reservatório tropical}

Este é um estudo de longo prazo (1993-1998) focalizado nos efeitos do aumento da eutrofização sobre a estrutura de crustáceos zooplanctônicos de um reservatório eutrófico. O estudo demonstra, primeiramente, que o avanço da eutrofização é um fenômeno bem descrito por uma única variável abiótica: o fósforo total. Durante o estudo, o zooplâncton sofreu extensas mudanças quali-quantitativas. Respostas significativas sobre o tamanho e a biomassa de determinados grupos do zooplâncton ao fósforo total foram encontrados. Esses resultados sugerem que essas variáveis devem sempre ser consideradas simultaneamente para avaliar os impactos causados pela eutrofização na estrutura do zooplâncton.

Palavras-chave: eutrofização, reservatório, zooplâncton, biomassa, alometria.

\section{INTRODUCTION}

Eutrophication is one of the most important human-induced modifications affecting aquatic systems in the biosphere. This phenomenon has long been studied but most of these investigations have concentrated on primary producers in temperate areas (Sakamoto, 1966; Brylinsky \& Mann, 1973; Dillon \& Rigler, 1974; Vollenweider, 1976; Canfield \& Bachmann, 1981; Prairie et al., 1989; Watson et al., 1992; Dodson et al., 2000; Masson et al., 2000). 
Modifications induced by eutrophication are often not limited to just one trophic level, and zooplankton responses to eutrophication have been studied in some cases (McCauley \& Kalff, 1981; Pace, 1984; Hanson \& Peters, 1984; Mazumder, 1994). Some of these studies have revealed contradictory trends in this community in response to eutrophication (Hulot et al., 2000). Furthermore, despite an increasing number of recent studies concerning the zooplankton community from tropical or subtropical systems (Mazumder \& Havens, 1998; Pinto-Coelho, 1998; Sendacz \& Kubo, 1999; Aka et al., 2000; Espíndola et al., 2000; Havens et al., 2000, Starling, 2000; Kozlowsky-Suzuki \& Bozelli, 2002; Sampaio et al., 2002; Neves et al., 2003), the bulk of investigations relating zooplankton to eutrophication is still concentrated on temperate areas.

The present study focused on a small tropical reservoir that has been suffering from increasing trophy for the last two decades: the Pampulha reservoir in Brazil. The main objective was to evaluate the modifications suffered by the community structure of crustacean zooplankton during this process. First, the power of a single abiotic variable, total phosphorus, was tested as a step in describing the eutrophication in this reservoir. Next, associations of crustacean zooplankton size and biomass with total phosphorus were assessed in order to investigate which of these biotic variables was more closely associated with eutrophication. The use of this approach can reveal significant responses to eutrophication, and is essential not only for monitoring but also for the understanding the impacts of eutrophication on higher trophic levels.

\section{MATERIAL AND METHODS}

\section{Study area}

Pampulha reservoir is located in the northern part of Belo Horizonte, capital of Minas Gerais State. It has a volume of $11 \times 10^{6} \mathrm{~m}^{3}$ and a surface are of $2.1 \mathrm{~km}^{2}$. The reservoir was built in 1938 for supplying water but in the early eighties the water plant had to be closed due to the incidence of cyanobacteria blooms in the lake. Since then, the reservoir has exhibited several signs of eutrophication, e.g., outbreaks of the macrophyte Eichhornia crassipes (1992-1995) and successive blooms of Microcystis aeruginosa (1980-1998).
Mesozooplankton (sensu Sieburth et al., 1978) have also suffered important changes during this period. The calanoid Scolodiaptomus corderoi and the cladoceran Ceriodaphnia cornuta disappeared from the lake in the middle of the nineties. Furthermore, the eutrophication of Pampulha has affected the temporal dynamics of most species of this community (Pinto-Coelho, 1998). Some large cladocerans, such as the dominant Daphnia laevis and D. gessneri, disappeared from the lake in 1997 and have yet to return. The dominance of this organism was succeeded by that of the small cyclopoid Thermocyclops decipiens. The disappearance of daphnids is probably associated with the sharp increase of an exotic fish population, the African cichlid Oreochromis niloticus, which occurred during this period in the reservoir (Álvares et al., 2000).

\section{Sampling and laboratory procedures}

Plankton organisms and water samples for chemical analysis were collected at a central station $(\mathrm{z}=8 \mathrm{~m})$ in the reservoir, which has been used for regular monitoring for more than 15 years. Different depths covering the water column were considered: $0,2,4$, and $6 \mathrm{~m}$. The sampling was done monthly between 1993 and 1995 and every two weeks from 1996 to 1998 . Zooplankton was collected with the use of a Schindler-Patalas 5.1 L trap, equipped with a $90 \mu \mathrm{m}$ mesh size collecting net. In this study, only zooplankton data from $2.0 \mathrm{~m}$ were used in analyses. Water transparency and electric conductivity were measured in situ by means of a $35 \mathrm{~cm}$ (diameter) Secchi disk and a Yellow Springs device, respectively.

Water samples for chemical analysis were deep frozen $\left(-25^{\circ} \mathrm{C}\right)$ just after collection. The determination of inorganic nitrogen (ammonium) was done according to Mackereth et al. (1978). Total phosphorus and chlorophyll- $a$ were established using the procedure described by Murphy \& Riley (1962) and Lorenzen (1967), respectively. Particulate organic carbon (POC) was estimated by the chemical digestion method of oxidation using $\mathrm{K}_{2} \mathrm{Cr}_{2} \mathrm{O}_{7}$, following a new procedure as improved by Torres et al. (1998).

Zooplankton was fixed using a buffered formalin solution ( $\mathrm{pH}=7.0$ ) saturated with sucrose. A minimum of 700 individuals were counted and measured in each sample using a M3C Leica dissecting stereomicroscope. Biomass estimation was done by using equations by Bottrell et al. (1976), Rosen (1981), Malley et al. (1989), Culver et al. 
(1985), and Masundire (1994) that relate length to dry weight. Early evaluations of the allometric coefficients for dominant Pampulha zooplankters showed a significant and positive relationship between biomass allometric and gravimetric determinations.

Statistical (Systat 8.0) and graphic (Sigma Plot 6.0) packages were used for statistical analysis and graphics, respectively.

\section{RESULTS}

\section{Physical and chemical variables}

The water quality of Pampulha reservoir reflected a eutrophication increase during the study period (Table 1). Despite seasonal variation, a clear long-term pattern of nutrient increase can be observed in most variables such as conductivity, ammonium, nitrate, and total phosphorus. The reservoir also showed increases in the annual maximum of ammonia but the long-term trend was not as clear as that observed with total phosphorus (TP) and conductivity. Eutrophication progress can also be attested to by the annual decreases in water transparency, as well as increases of chlorophyll$a$ and particulate carbon in the trophogenic zone. Water transparency, for instance, showed a longterm reduction, with all measurements being under $1.0 \mathrm{~m}$ in 1998 (Table 1, Fig. 1-B).

Some variables show clearer patterns of eutrophication progress at specific depths, which was the case of electric conductivity, ammonium, and total phosphorus (TP) at $6 \mathrm{~m}$, and of chlorophyll$a$, particulate organic carbon (POC), and nitrate for the trophogenic zone (0-2 m) (Fig. 1).

At the bottom (6 m), values of TP, ammonium, and conductivity (Fig. 1-A, 1-B) always increased their maximum annual values in the study period. The mean annual value of TP concentrations rose from 53.8 to $234.0 \mu \mathrm{g} . \mathrm{P}-\mathrm{PO}_{4} \cdot \mathrm{L}^{-1}$ in this study period (Fig. 1-A). Like TP, electric conductivity values also suffered a major increase and the mean annual values increased from $267 \mu \mathrm{S} . \mathrm{cm}^{-1}$ to $317 \mu \mathrm{S} . \mathrm{cm}^{-1}$ (Table 1, Fig. 1-B).

Sestonic carbon as well as chlorophyll- $a$ amounts also exhibited clear trends of long-term increase during the study period (Fig. 1-C). Chlorophyll- $a$ concentrations were particularly high in 1997-1998, after the cladocerans decline (see below). The annual maxima for chlorophyll$a$ in the 1996-1998 period were 48.8, 123.2, and
$244.6 \mu \mathrm{g} . \mathrm{L}^{-1}$, respectively. After complete macrophyte removal in 1995, there was a pulse, reaching a maximum of $7.8 \mathrm{mgC} . \mathrm{L}^{-1}$, in sestonic POC concentrations. In 1996, POC concentrations were somewhat lower (annual maximum of 7.0 mgC. $\mathrm{L}^{-1}$ ) but this variable again showed increases in 1997 and 1998 with annual maxima of 12.1 and $15.0 \mathrm{mgC} . \mathrm{L}^{-1}$, respectively.

The chemical composition of the reservoir water column has a typical seasonal cycle with higher nutrient values being found during the dry season, especially between July and October (Fig. 1). During the rainy season, which usually begins in November, a sharp decrease in concentrations of conductivity and inorganic nutrients has been observed in most years.

\section{Zooplankton size}

Cladoceran size showed large variations (Fig. 2-A), with the mean showing a slight increase from $0.65 \mathrm{~mm}$ in 1993 to $0.86 \mathrm{~mm}$ in 1998 (Table 2). The trend towards cladoceran size increase is also visible when all values are plotted against time. In 1997 and 1998, cladoceran size showed large variations between successive samplings but retained fairly high values, above $0.7 \mathrm{~mm}$ in most cases.

The size distribution of cyclopoid (represented mostly by the small cyclopoid Thermocyclops decipiens) also underwent large variations (Fig. 2A). During 1993-1995, the mean size usually remained below $0.5 \mathrm{~mm}$. In 1996, cyclopoid size suffered a great increase, continuing above $0.6 \mathrm{~mm}$ for most of the time (annual mean was $0.58 \mathrm{~mm}$ ). This period coincided with the dominance of Daphnia laevis in the reservoir. However, after 1996 the mean size went down, usually remaining below $0.4 \mathrm{~mm}$, and the annual means were 0.28 and $0.38 \mathrm{~mm}$ for 1997 and 1998, respectively (Table 2). This is probably due to the high dominance of nauplii of $T$. decipiens in the samples from this period.

\section{Zooplankton biomass}

The temporal evolution of crustacean zooplankton showed a complex pattern of long- term succession characterized first by the disappearance of calanoids, followed in 1995 and 1996 by a large cladoceran biomass development, especially of daphnids (Fig. 2-B, Table 3). The third and last event covered in this study was the dominance of cyclopoids (Thermocyclops decipiens) beginning in 1997 and throughout 1998 (Fig. 2-B). 


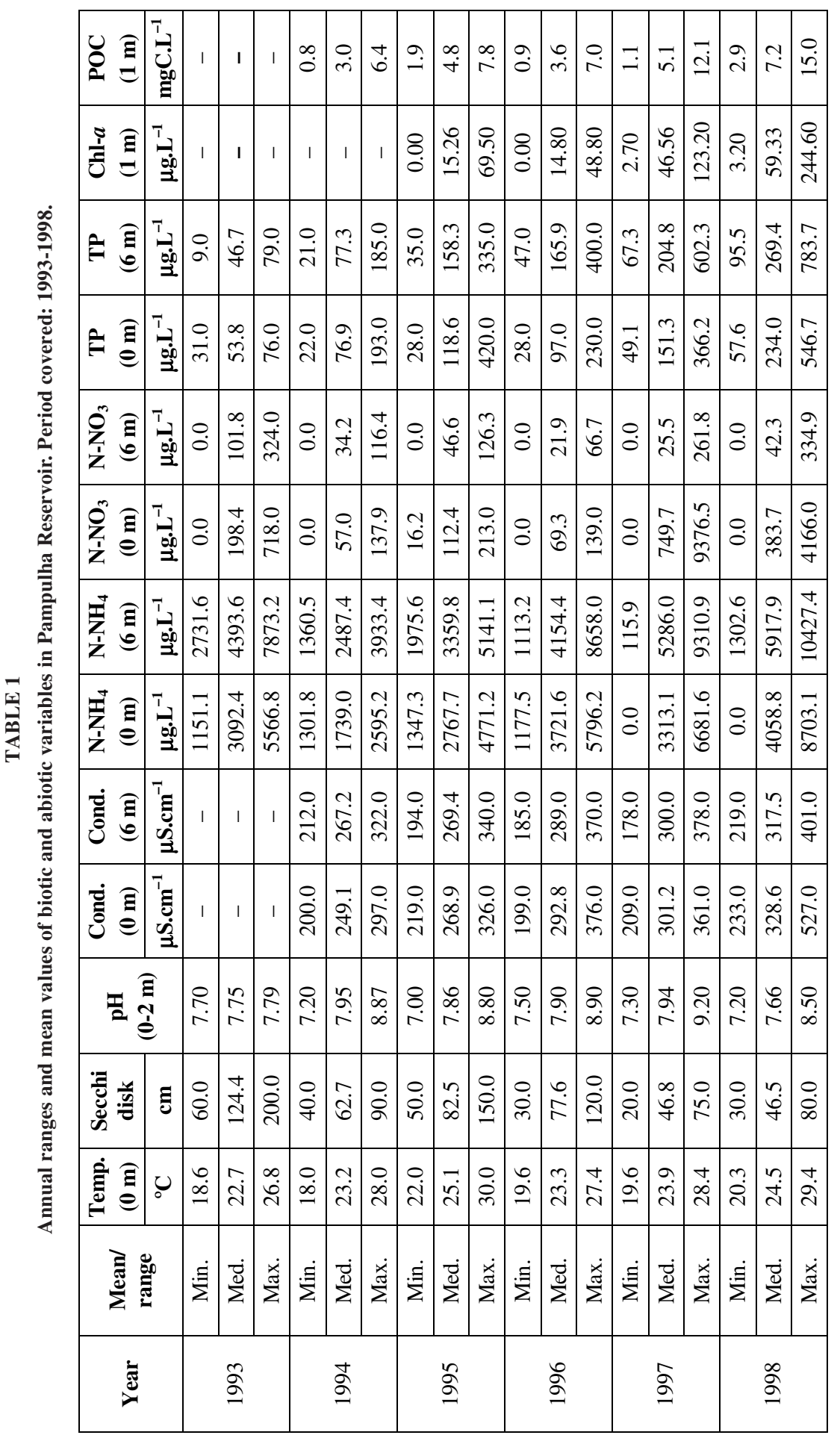


Cladocerans were the dominant zooplankters until late 1996. Between 1993 and 1995, this taxocenosis consisted of two species of Daphnia (D. gessneri and D. laevis), Diaphanosoma birgei, and the small cladocerans Bosmina longirostris, B. hagmanni, and Ceriodaphnia cornuta. After the removal of macrophyte beds in 1995 , D. laevis practically dominated the cladoceran community, showing several population peaks in 1995 and 1996. During this time, the biomass of cladocerans reached a maximum of $4263 \mathrm{mgDW} \cdot \mathrm{m}^{-3}$ (Table 3). After the disappearance of Daphnia in 1997, the cladoceran group was dominated by Moina micrura. In the 1997-1998 period, the maximum biomass reached by cladocerans was only $545 \mathrm{mgDW} \cdot \mathrm{m}^{-3}$ (Fig. 2-B, Table 3).

Cyclopoids in Pampulha showed distinct temporal patterns of biomass (Fig. 2-B). The cyclopoid biomass pattern can be divided into two phases: a period of lower biomass (1993-1996) and a second with higher biomass (1997-1998). The maximum biomass during the first period did not surpass 204 $\mathrm{mgDW} \cdot \mathrm{m}^{-3}$. The second phase occurred after the end of the daphnid dominance period in late 1996, when the biomass of cyclopoids responded with a vigorous increase. Values as high as $1829 \mathrm{mgDW} . \mathrm{m}^{-3}$ (Fig. 2-B, Table 3) were found in this Daphnia-free period.

A single species of calanoid, Scolodiaptomus corderoi, was present in the reservoir. Although never building up large populations, when present they were the largest organisms in the samples (Fig. 2-B). Between 1993 and 1996, the biomass values of this group of copepods never reached values higher than 102 mgDW.m ${ }^{-3}$, observed in 1993.

\section{Statistical analysis}

Most eutrophication models are based on empiric relationships between abiotic variables such as Secchi disk measurements, total phosphorus (TP), and biomass of producers (chlorophyll- $a$ ). Therefore, a series of regressions were performed considering abiotic variables commonly used in eutrophication studies. In all of them, TP was used as independent variable (Fig. 3). For these regressions, the same depths as those represented in Fig. 1 (see above) were considered. As expected, TP showed a significant and inverse linear regression with water transparency and strong positive linear associations with conductivity and ammonium. The coefficient $r^{2}$ for these regressions were, respectively, $0.199(n=104, \mathrm{p}<0.0001)$ for transparency vs. TP; $0.378(n=104, \mathrm{p}<0.0001)$ for conductivity vs. TP; and $0.094(n=107, \mathrm{p}=0.0014)$ for ammonium vs. TP.

Linear regressions between TP and chlorophyll$a$ and particulate organic carbon (Fig. 3) also were significant, with the highest $\mathrm{r}^{2}$ coefficients of 0.235 $(n=78, \mathrm{p}<0.0001)$ for chlorophyll- $a$ and $\mathrm{r}^{2}=0.422$ ( $n=94, \mathrm{p}<0.0001)$ for POC. Thus, this set of regressions confirmed that $\mathrm{TP}$ can be a good descriptor of trophic grade in Pampulha reservoir.

A series of linear regressions using the major groups of crustacean zooplankton size (Fig. 4) and biomass (Fig. 5), and TP as the sole independent variable were also performed.

TABLE 2

Annual ranges and mean values of size $(\mathrm{mm})$ of crustacean zooplankton in Pampulha reservoir during the period 1993-1996.

\begin{tabular}{|c|c|c|c|c|c|c|c|c|c|}
\hline \multirow{2}{*}{ Year } & \multicolumn{3}{|c|}{ Cyclopoida (mm) } & \multicolumn{3}{c|}{ Calanoida (mm) } & \multicolumn{3}{c|}{ Cladocera (mm) } \\
\cline { 2 - 11 } & Min. & Med. & Max. & Min. & Med. & Max. & Min. & Med. & Max. \\
\hline 1993 & 0.1 & 0.29 & 0.75 & 0.5 & 0.7 & 1 & 0.4 & 0.65 & 1.2 \\
\hline 1994 & 0.2 & 0.43 & 0.6 & 0.7 & 0.9 & 1.2 & 0.6 & 0.74 & 0.8 \\
\hline 1995 & 0.1 & 0.29 & 0.4 & 0 & 0.4 & 1.1 & 0.5 & 0.73 & 0.9 \\
\hline 1996 & 0.2 & 0.58 & 1 & - & - & - & 0.7 & 0.84 & 1.1 \\
\hline 1997 & 0.2 & 0.28 & 0.7 & - & - & - & 0.6 & 0.87 & 1.3 \\
\hline 1998 & 0.2 & 0.38 & 0.7 & - & - & - & 0.4 & 0.86 & 1.2 \\
\hline
\end{tabular}



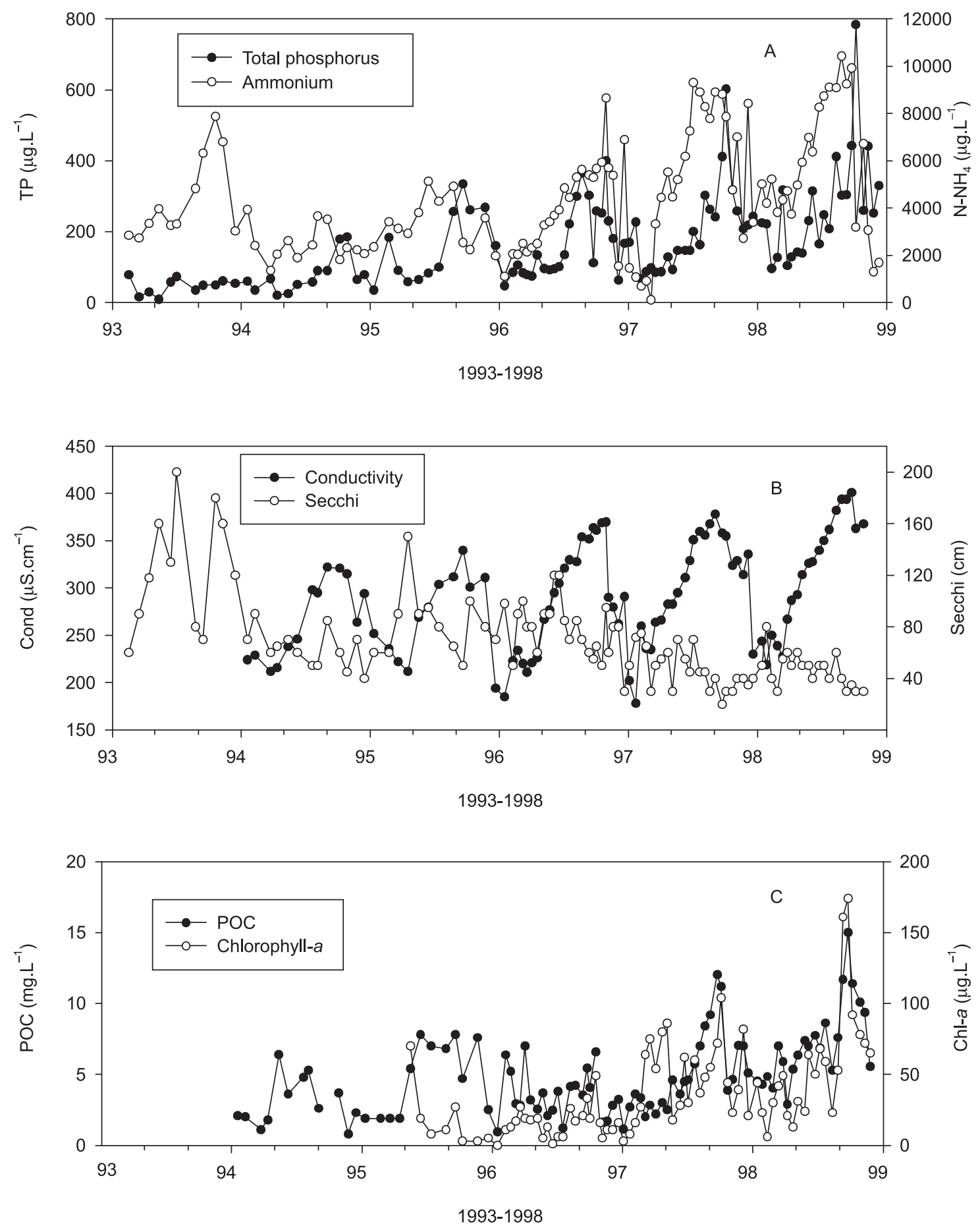

Fig. 1 - Temporal variation of total phosphorus $(6 \mathrm{~m})$ and ammonium $(6 \mathrm{~m})(\mathrm{A})$; electric conductivity $(6 \mathrm{~m})$ and water transparency (B) and particulate organic carbon and chlorophyll- $a$ (1 m) (C) in Pampulha reservoir (1993-1998). TP = total phosphorus, N$\mathrm{NH}_{4}=$ ammonium, COND = electric conductivity, Secchi = water transparency, POC = particulate organic carbon, and Chl- $a=$ chlorophyll- $a$. 
The regressions between size and total phosphorus were not significant for Calanoida and Cyclopoida (Fig. 4), but this regression was significant for cladocerans $\left(\mathrm{r}^{2}=0.143, n=105\right.$, $\mathrm{p}<0.0001)$.

The biomass of Cladocera and Calanoida (Fig. 5) showed no significant relationship with total phosphorus. However, a significant relationship was found with the biomass of Cyclopoida $\left(\mathrm{r}^{2}=0.15\right.$, $n=105, \mathrm{p}<0.0001)$.

\section{DISCUSSION}

The limnological conditions of Pampulha reservoir during the past decade can be characterized by increasing input of essential nutrients that caused a clear increase in the system's trophic conditions. Early eutrophication signs were observed in the seventies (Giani et al., 1988). A recent study confirmed the progress of eutrophication in the reservoir and its impact on the temporal dynamics of zooplankton (Pinto-Coelho, 1998). Torres \& Pinto-Coelho (submitted) estimated the contribution of each incoming stream to the total nitrogen and phosphorus balance of the reservoir. They estimated the annual nutrient amount for 1998 of all tributaries pooled together to be as high as 655 ton.year $^{-1}$, with 4862 ton.year $^{-1}$ registered for inorganic phosphorus and nitrogen, respectively. Thus, the phenomenon is basically caused by untreated wastewater flowing into the tributaries of this reservoir.

A significant linear relationship between chlorophyll- $a$ and total phosphorus was found for this 5-year period, confirming that TP is a good descriptive variable for eutrophication in this reservoir. There is vast amount of literature indicating the robustness of the linear relationship between chlorophyll- $a$ and TP (see OECD, 1982). However, a stronger relationship was found between TP and POC, which may indicate the relative importance of the detrital food chain for the planktonic community in the reservoir. In fact, this was confirmed by two previous investigations (Araújo \& Pinto-Coelho, 1998; Pinto-Coelho, 1998). Araújo \& Pinto-Coelho (1998) demonstrated that the reservoir frequently displays an unbalance between primary and secondary production. The high values of zooplankton assimilation (up to 486 $\mathrm{mgC} \cdot \mathrm{m}^{-2} \cdot \mathrm{d}^{-1}$ ) can only be balanced by additional intake of non-pigmented food particles. The maximum value for primary production was 206 $\mathrm{mgC} \cdot \mathrm{m}^{-2} \cdot \mathrm{d}^{-1}$.

A significant linear regression between biomass of cyclopoids and total phosphorus was found, suggesting that zooplankton reacts to eutrophication by increasing the biomass at least in some major groups. This is confirmed by the findings of Hanson \& Peters (1984) who found a strong linear relationship between total phosphorus and total zooplankton biomass in 49 lakes of various types, most of them located in North America and Europe.

In this study, no TP effect on the biomass of other crustacean zooplankton groups such as cladocerans and calanoids was found. This is partially explained by the disappearance of the dominant zooplankters, Daphnia, from the lake in early 1997 (Pinto-Coelho et al., 2003).

TABLE 3

Annual ranges and mean values of biomass $\left(\mathrm{mgDW}^{-3} \mathrm{~m}^{-3}\right.$ of crustacean zooplankton in Pampulha reservoir during the period 1993-1996.

\begin{tabular}{|c|c|c|c|c|c|c|c|c|c|}
\hline \multirow{2}{*}{ Year } & \multicolumn{3}{|c|}{$\begin{array}{c}\text { Cyclopoida } \\
\left(\mathbf{m g ~ D W . m}^{-3}\right)\end{array}$} & \multicolumn{3}{c|}{$\begin{array}{c}\text { Calanoida } \\
\left(\mathbf{m g ~ D W . m}^{-3}\right)\end{array}$} & \multicolumn{3}{c|}{$\begin{array}{c}\text { Cladocera } \\
\left(\mathbf{m g ~ D W . m}^{-3}\right)\end{array}$} \\
\cline { 2 - 11 } & Min. & Med. & Max. & Min. & Med. & Max. & Min. & Med. & Max. \\
\hline 1993 & 0.40 & 11.34 & 33.40 & 0.80 & 29.23 & 102.70 & 0.30 & 158.00 & 555.90 \\
\hline 1994 & 4.20 & 68.91 & 149.90 & 0.00 & 4.25 & 19.50 & 23.10 & 321.28 & 821.20 \\
\hline 1995 & 10.40 & 71.75 & 204.80 & 0.00 & 8.78 & 40.00 & 26.30 & 463.35 & 2161.00 \\
\hline 1996 & 0.40 & 18.08 & 54.20 & 0.00 & 0.00 & 0.00 & 1.90 & 572.16 & 4263.00 \\
\hline 1997 & 2.40 & 379.51 & 1829.70 & 0.00 & 0.00 & 0.00 & 0.00 & 144.10 & 545.50 \\
\hline 1998 & 0.00 & 263.34 & 1688.50 & 0.00 & 0.00 & 0.00 & 0.80 & 40.42 & 105.00 \\
\hline
\end{tabular}


As a consequence, a sharp decline occurred in the biomass of the group of cladocerans in subsequent years, regardless of further TP increases.

Despite their potential for reacting to environmental changes, zooplankton has not yet been widely used to indicate ecosystem conditions (Stemberger \& Lazorschak, 1994). Pinto-Coelho (1998) suggested that the seasonal patterns of some zooplankton species may be affected by eutrophication. Nevertheless, the responses of zooplankton to eutrophication are not always clear and, in some cases, contradictory results may appear such as decreasing biomass or increasing species richness (Hulot et al., 2000). Some authors suggest that the presence of some key herbivores like Daphnia can modify completely not only the response of structural variables of the zooplankton community to eutrophication but also the relation between TP and chlorophyll- $a$ (Pace, 1984). This finding was confirmed by Mazumder (1994), who showed that the higher grazing pressure existing in Daphnia-dominated systems produces a lower chlorophyll- $a$ accumulation. In Pampulha lake we observed that the POC and chlorophyll- $a$ concentrations increased sharply in 1997 and 1998 just after the daphnids disappeared from the lake.

The lack of any significant relationship between calanoids and TP was not a surprise. On the contrary, it was an expected result. Calanoids are considered to be good indicators of oligotrophy in the tropical reservoirs of Brazil, and good documentation confirms that calanoids are rare and often disappear from reservoirs that become eutrophic (Sendacz, 1984; Arcifa, 1984).

Some authors suggest that, rather than biomass, variables linked to the community structure (size, species richness) would be better descriptors for assessing eutrophication impacts on a zooplankton community (Pace, 1984; MatsumuraTundisi, 1999). One of these descriptors would be the size of zooplankton. However, this variable has been studied mostly in temperate regions and rarely in tropical ones. In our research, we found a significant relationship between $\mathrm{TP}$ and size of cladocerans. Between 1993 and 1995, the cladocerans in Pampulha were represented by a more diverse array of species including some small cladocerans such as Bosmina and Ceriodaphnia (Pinto-Coelho, 1998). Between 1995 and 1997, the biomass of cladoceran increased sharply mostly due to the population pulses of Daphnia laevis. After the disappearance of Daphnia in early 1997, the biomass of cladoceran diminished but another relatively large cladoceran was always present: Moina micrura.

Understanding modifications of the structure of the zooplankton community in response to nutrient increases in Pampulha reservoir also demands a review of the phenomena affecting other trophic levels. Three such phenomena occurred in the lake, affecting primary producers and fishes.

This first phenomenon was a large development of the macrophyte water hyacinth (Eichhornia crassipes). During 1992-1994, water hyacinth stands sometimes covered up to $50 \%$ of the total reservoir surface. This plant biomass accumulation caused problems such as mosquito propagation, causing the city administration to undertake an intensive plant removal program that took place in late 1994 and the beginning of 1995. The major impacts of macrophyte removal in water chemistry as well on zooplankton organisms were described by Pinto-Coelho \& Araújo (1997). Shortterm decreases in ammonium and corresponding increases in nitrate concentrations were observed shortly after plant removal. Furthermore, the disappearance of the calanoid Scolodiaptomus corderoi as well as the smaller cladocerans Bosmina and Ceriodaphnia were also associated with this plant removal. The seasonal cycle of production and decomposition of macrophyte biomass, taking into account plant production, as well as the contribution of dead-plant decomposition to the internal nutrient load, was investigated by Pinto-Coelho \& Greco (1999). It was shown that macrophyte decomposition could return as much as $90 \mathrm{mg}$ P-PO4. $\mathrm{m}^{-2} \cdot \mathrm{d}^{-1}$ (March $1995)$ to the lake water. Thus, macrophyte removal also affected the internal cycling of potential limiting nutrients such as phosphorus.

The second phenomenon was the cyanobacterial increase in the reservoir. The macrophyte removal was an opportunity for a large outbreak of the cyanobacteria Microcystis spp. Seasonal development as well as the diel cycles of vertical migration of the cyanobacteria were studied by Goodwin (1997). The temporal patterns of major biochemical properties of the seston have also been investigated (Boechat, 2000). Both studies demonstrated the key role of cyanobacteria in the overall metabolism of phytoplankton and seston in Pampulha reservoir.

The increase in the cyanobacterial biomass also induced important modifications in zooplankton 
structure and metabolism that has been discussed elsewhere (Pinto-Coelho et al., 2005).

The third phenomenon was related to the population increase of Oreochromis niloticus in the lake. Godinho et al. (1992) performed an inventory of local fauna, sampling 944 specimens in different regions of the reservoir. Tilapias were already the dominant organisms with $82.4 \%$ of the total catch. Other species such the piscivorous traíra (Hoplias lacerdae, H. malabaricus) and a small piranha,
Serrasalmus sp. were also common. However, after 1997 the population of this exotic African fish became largely dominant in the reservoir. In 1999, another inventory of the fish fauna was made.

About 1200 specimens were collected, weighed, and identified, all of them belonging to two genera of the African cichlids (tilapias), and the vast majority belonging to a single species, i.e., O. niloticus. However, a second species (Tillapia rendalli) was also present (Álvares et al., 2000).
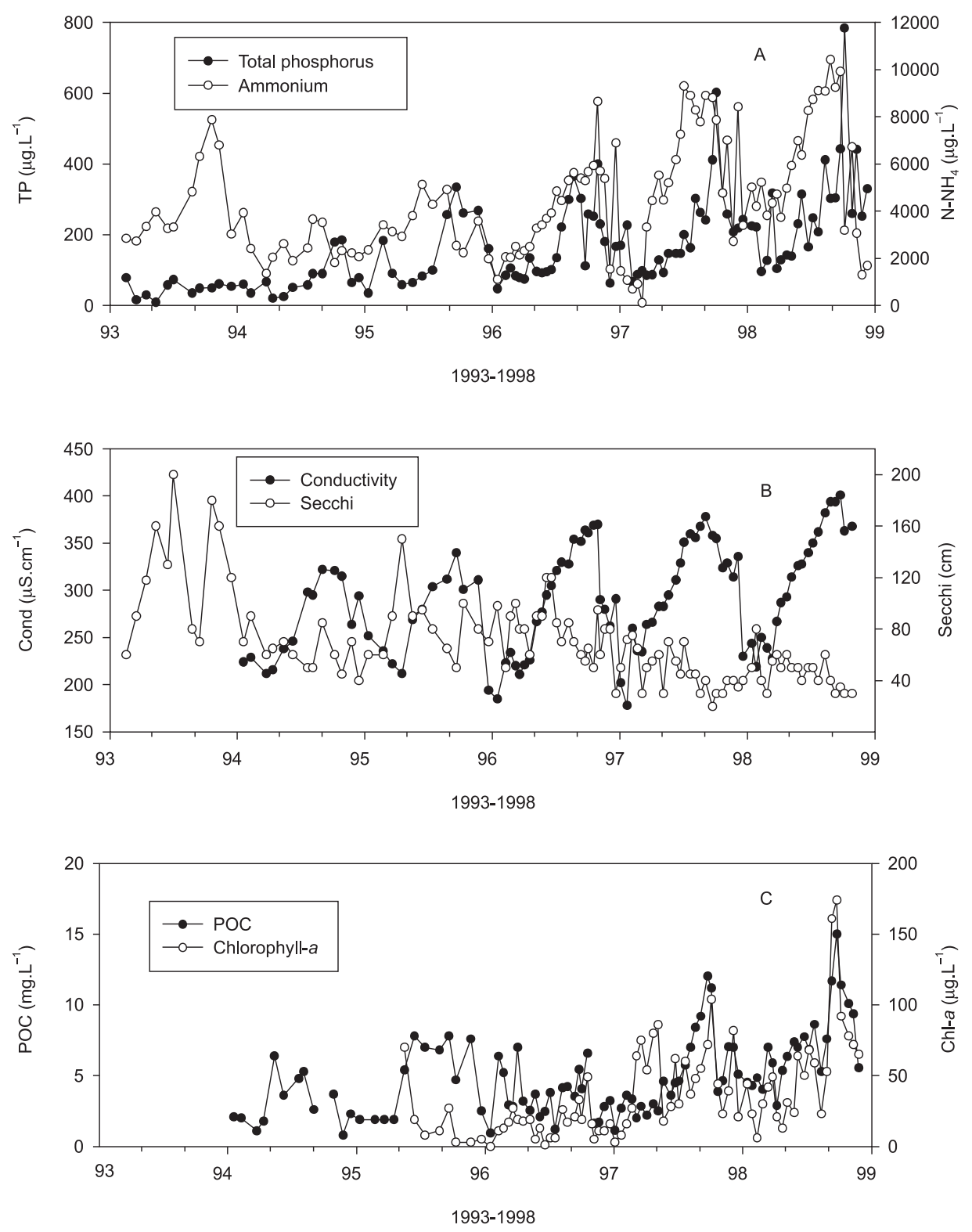

Fig. 2 - Temporal variation of size (A) and biomass (B) of zooplankton groups in Pampulha reservoir (1993-1998). 
The annual output of tilapias ranged between 205 and $410 \mathrm{~kg} \cdot \mathrm{ha}^{-1} \cdot \mathrm{year}^{-1}$. The dramatic increase of the tilapia population in the reservoir may explain the disappearance of Daphnia and the increase of small cyclopoids in the lake. Recently, Meschiatti \& Arcifa (2002), working in a shallow eutrophic reservoir, demonstrated that Tilapia rendalli exhibit microcrustacean content of up to $11.5 \%$ in their gut volume.

The key role of top-down forces on delimiting the distribution of size classes of zooplankton in lakes has long been established (Hrbácek et al., 1961; Brooks \& Dodson, 1965).
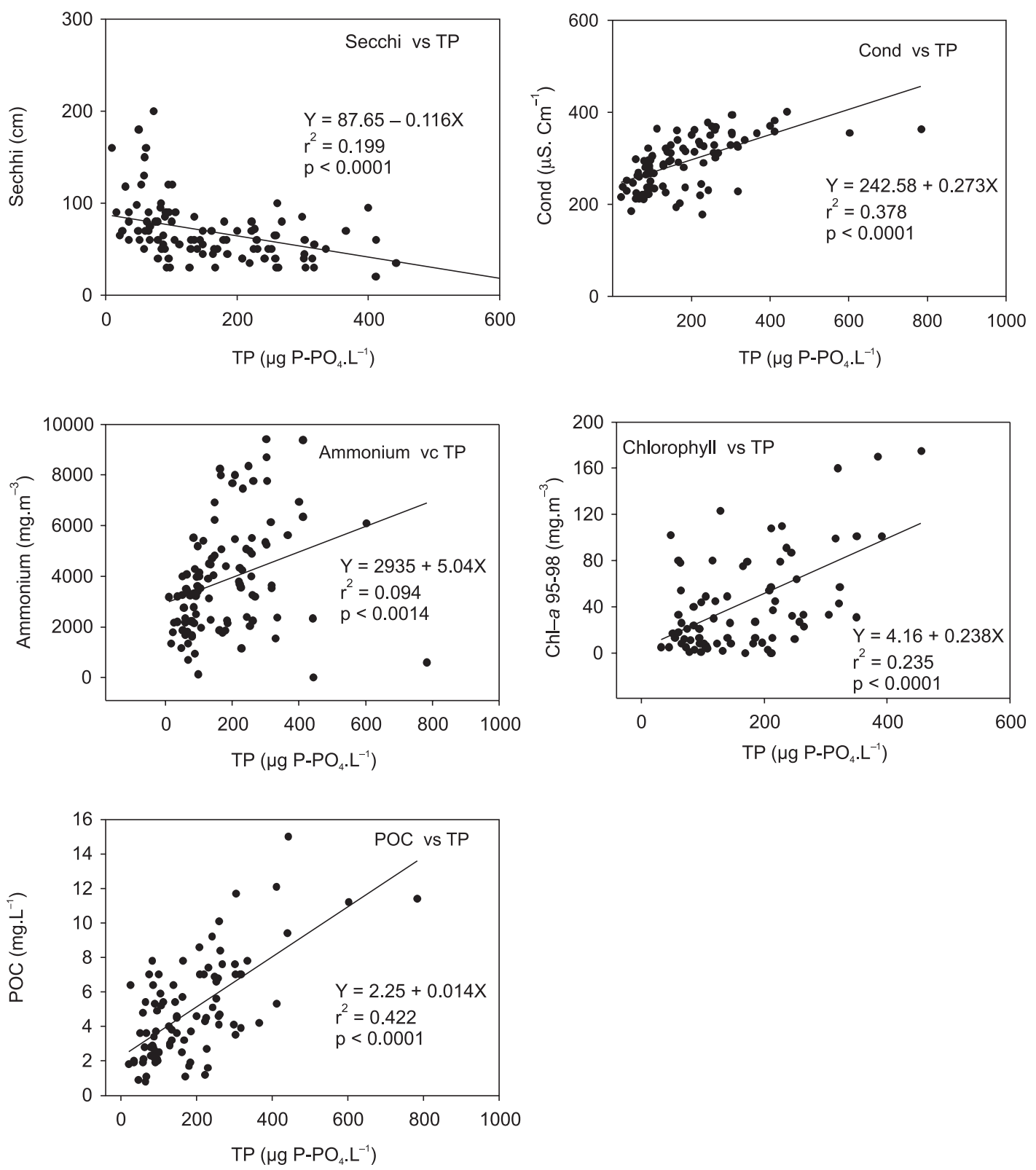

Fig. 3 - Linear regressions between abiotic variables associated with eutrophication in Pampulha reservoir (pooled data: 1993-1998). $\mathrm{TP}=$ total phosphorus $(6 \mathrm{~m})$, Cond = electric conductivity $(6 \mathrm{~m}), \mathrm{Chl}-a=$ Chlorophyll- $a(1 \mathrm{~m}), \mathrm{POC}=$ particulate organic carbon $(1 \mathrm{~m})$. Secchi $=$ water transparency and ammonium $(6 \mathrm{~m})$. 

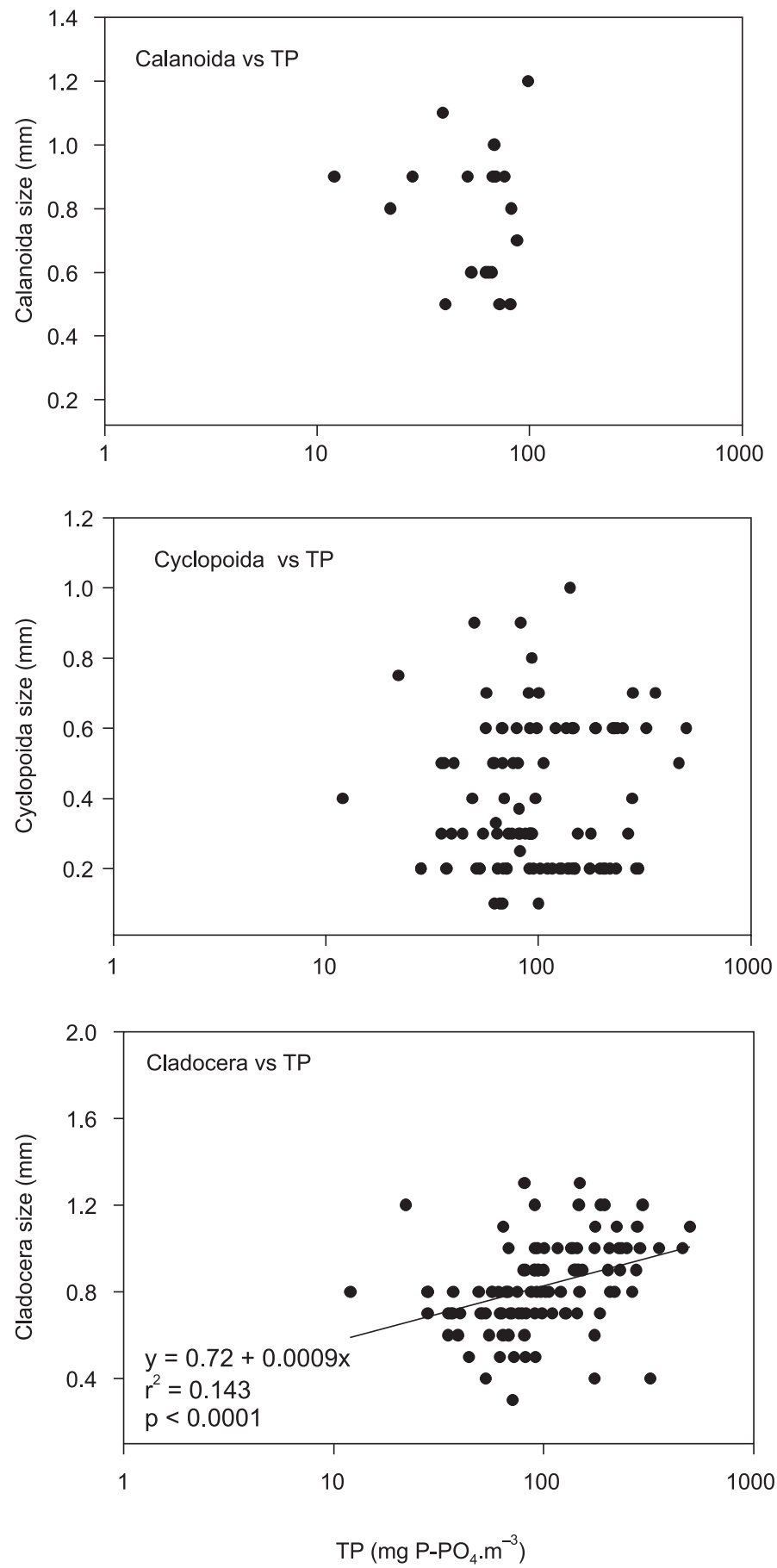

Fig. 4 - Linear regression between total phosphorus (TP) and size of crustacean zooplankton in Pampulha reservoir (1993-1998).

In lakes where fish pressure is intense, zooplankton communities tend to be smaller. The effect of eutrophication on size distribution of zooplankton is far less understood, possibly because the fish community is also affected by this phenomenon. Some authors even argue that top-down forces can cause major shifts in the response patterns of zooplankton to eutrophication (Hulot et al., 2000). 

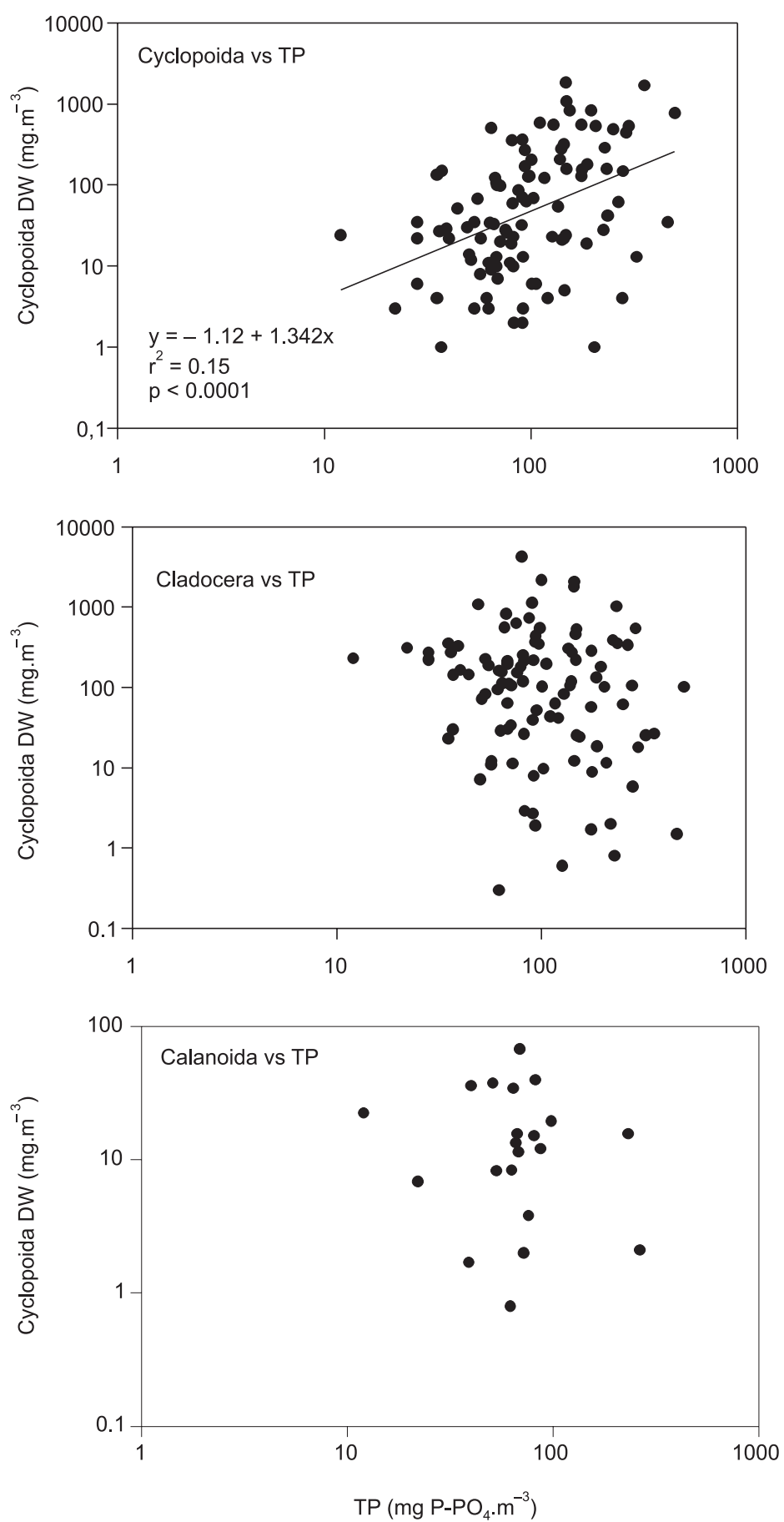

Fig. 5 - Linear regression between total phosphorus (TP) and biomass of crustacean zooplankton in Pampulha reservoir (1993-1998).

Despite the complexity and simultaneous interplay of different factors that could possibly have affected the zooplankton structure in Pampulha reservoir during the past decade, significant responses of zooplankton size and biomass could be identified with respect to a variable closely associated to 
eutrophication, i.e., total phosphorus. The size of cladocerans was less affected by piscivorous predation than was the total biomass of this group, which suffered clear reductions. On the other hand, the cyclopoids responded to increased fish predation and eutrophication by increasing the biomass of the group, in particular the relative proportion of the naupliar and young copepodite stages. Thus, the present study suggested that the effects of eutrophication on the structure of zooplankton can be better assessed if the analysis is not restricted to abundance signals but also if the size and biomass of major zooplankton groups are taken into consideration.

Acknowledgements - We thank the city of Belo Horizonte for supporting this research (grant 3998, FUNDEP/SMMA/PBH) and the National Research Council $(\mathrm{CNPq})$ for a research grant given to Ricardo M. Pinto-Coelho. We also thank an anonymous referee for a careful review and suggestions that significantly improved the manuscript.

\section{REFERENCES}

AKA, M., PAGANO, M., SAINT-JEAN, L., ARFI, R., BOUVY, M., CECCHI, P. \& CORBIN, D., 2000, Zooplankton variability in 49 shallow tropical reservoirs of Ivory Coast (West Africa). International Review of Hydrobiology, 85: 491-504.

ÁLVARES, E., CANELAS, M. A. S., COSTA, R. G., DIAS, L. G., RIBEIRO-MENDES, H. N. \& PINTO-COELHO, R. M., 2000, Aspectos socioeconômicos e estimativa da atividade de pesca no reservatório da Pampulha, Belo Horizonte, MG. Anais V Simpósio de Ecossistemas Brasileiros, Vitória, Brasil, pp. 375-382.

ARAÚJO, M. A. \& PINTO-COELHO, R. M., 1998, Produção e consumo de carbono orgânico na comunidade planctônica da represa da Pampulha, Belo Horizonte, MG. Rev. Bras. Biol., 58: 403-414.

ARCIFA, M. S., 1984, Zooplankton composition of ten reservoirs in Southern Brazil. Hydrobiologia, 113: 137-145.

BOECHAT, I. G., 2000, Modificações na composição bioquímica do seston no reservatório da Pampulha, MG, ao longo de ciclos nictemerais, com ênfase na comunidade fitoplanctônica. Dissertação de Mestrado, Universidade Federal de Minas Gerais, Belo Horizonte, 96p.

BOTTRELL, H. H., DUNCAN, A., GLIWICZ, Z. M., GRYGIEREK, E., HERZIG, A. \& HILLBRICHT-ILKOWS, A., 1976, A review of some problems in zooplankton production studies. Norw. J. Zool., 24: 419-456.

BROOKS, J. L. \& DODSON, S. I., 1965, Predation, body size and composition of plankton. Science, 150: 28-35.

BRYLINSKY, M. \& MANN, K. H., 1973, An analysis of factors governing productivity in lakes and reservoirs. Limnol. Oceanogr., 18: 1-14.
CANFIELD, D. E. \& BACHMANN, R. W., 1981, Prediction of total phosphorus concentrations, chlorophyll-a and Secchi depths in natural and artificial lakes. Can. J. Fish. Aquat. Sci., 38: 414-423.

CULVER, D. A., BOUCHETE, M. M., BEAN, D. J. \& FLETCHER, J. W., 1985, Biomass of freshwater crustacean zooplankton from length-weight regressions. Can. J. Fish. Aquat. Sci., 42: 1380-1390.

DILLON, P. J. \& RIGLER, F. H., 1974, The phosphorus-chlorophyll relationship in lakes. Limnol. Oceanogr., 19: 767-773.

DODSON, S. I., ARNOTT, S. E. \& COTTINGHAM, K. L., 2000, The relationship in lake communities between primary productivity and species richness. Ecology, 81: 2662-2679.

ESPÍNDOLA, E. L. G., MATSUMURA-TUNDISI, T., RIETZLER, A. C. \& TUNDISI, J. G., 2000, Spatial heterogeneity of the Tucuruí reservoir (State of Pará, Amazonia, Brazil) and the distribution of zooplanktonic species. Rev. Bras. Biol., 60: 179-194.

GIANI, A., PINTO-COELHO, R. M., OLIVEIRA, S. M. \& PELLI, A., 1988, Ciclo sazonal de parâmetros físico-químicos da água e distribuição horizontal de nitrogênio e fósforo no reservatório da Pampulha (Belo Horizonte, MG, Brasil). Ciência e Cultura, 40: 69-77.

GODINHO, H., SANTOS, G. B., ALVES, C. B. M. \& FORMAGIO, P., 1992, Os peixes e a pesca na represa da Pampulha, Belo Horizonte, MG, pp. 134-142. In: H. Godinho (ed.), Anais do seminário da bacia hidrográfica da Pampulha. Segrac, Belo Horizonte, 186p.

GOODWIN, K. L., 1997, Dinâmica das populações de cianobactérias no reservatório da Pampulha (Minas Gerais) em duas escalas temporais (sazonal e diurna). Dissertação de Mestrado, Universidade Federal de Minas Gerais, Belo Horizonte, 112p.

HANSON, J. \& PETERS, R. H., 1984, Empirical prediction of crustacean zooplankton biomass and profundal macrobenthos biomass in lakes. Can. J. Fish. Aquat. Sci., 41: 439-445.

HAVENS, K., EAST, T. L., MARCUS, J., ESSEX, P., BOLAN, B., RAYMOND, S. \& BEAVER, J. R., 2000, Dynamics of the exotic Daphnia lumholzi and the native macro-zooplankton in a subtropical chain-of-lakes in Florida, USA. Freshwat. Biol., 45: 21-32.

HRBÁCEK, J., DVORAKOVA, M., KORINEK, V. \& PROCHAZKOVA, L., 1961, Demonstration of the effect of fish stock on species composition of zooplankton and the intensity of metabolism of the whole plankton assemblage. Verh. Internat. Verein. Limnol., 14: 192-195.

HULOT, F. D., LACROIX, G., LESCHER-MOUTOUE, F. \& LOREAU, M., 2000, Functional diversity governs ecosystem response to nutrient enrichment. Nature, 405: 340-344.

KOZLOWSKY-SUZUKI, B. \& BOZELLI, R. L., 2002, Experimental evidence of the effect of nutrient enrichment on the zooplankton in a Brazilian coastal lagoon. Braz. J. Biol., 62: 835-846.

LORENZEN, C. J., 1967, Determination of chlorophyll and phaeopigments: spectrophotometric equations. Limnol. Oceanogr, 12: 343-346. 
MACKERETH, F. J. H., HERON, J. \& TALLING, J. F., 1978 Water analysis: some revised methods for limnologists. Freshwater Biol. Assoc. Scientific. Publication 36, Cumbria, UK, 120p.

MALLEY, D. F., LAWRENCE, S. G., MACIVER, M. A. \& FINDLAY, W. J., 1989, Range of variation in the estimate of dry weight for planktonic crustacea and rotifera from temperate North American lakes. Can. Tech. Rep. of Fish. Aquat. Sci., 1666: 1-49.

MASSON, S., PINEL-ALLOUL, B. \& SMITH, V. H., 2000, Tota phosphorus-chlorophyll a size fractions relationships in southern Quebec lakes. Limnol. Oceanogr., 45: 732-740.

MASUNDIRE, H. M., 1994, Mean individual dry weight and length weight regressions of some zooplankton of lake Kariba. Hydrobiologia, 272: 231-238.

MATSUMURA-TUNDISI, T., 1999, Diversidade de zooplâncton em represas do Brasil, pp. 39-54. In: R. Henry (ed.), Ecologia de reservatórios: estrutura, função e aspectos sociais. Fundibio: Fapesp, São Paulo, 800p.

MAZUMDER, A., 1994, Phosphorus-chlorophyll relationships under contrasting zooplankton community structure: Potential mechanisms. Can. J. Fish. Aquat. Sci., 51: 401-407.

MAZUMDER, A. \& HAVENS, K. E., 1998, Nutrient-chlorophyllSecchi relationships under contrasting grazer communities of temperate versus subtropical lakes. Can. J. Fish. Aquat. Sci., 55: $1652-1662$

McCAULEY, E. \& KALFF, J., 1981, Empirical relationships between phytoplankton and zooplankton biomass in lakes. Can. J. Fish Aquat. Sci., 38: 458-463.

MESCHIATTI, A. J. \& ARCIFA, M. S., 2002, Early stages of fish and the relationships with zooplankton in a tropical Brazilian reservoir: lake Monte Alegre. Braz. J. Biol., 62(1): 41-50.

MURPHY, J. \& RILEY, J. P., 1962, A modified single solution method for the determination of phosphate in natural waters. Analytica Chimica Acta, 27: 31-36.

NEVES, I. F., ROCHA, O., ROCHE, K. F. \& PINTO, A. A., 2003, Zooplankton community structure of two marginal lakes of the river Cuiabá (Mato Grosso, Brazil) with analysis of Rotifera and Cladocera diversity. Braz. J. Biol., 63: 329-343.

ORGANIZATION FOR ECONOMIC CO-OPERATION AND DEVELOPMENT, 1982, Eutrophication of waters: monitoring, assessment and control (Vollenweider, R. A. \& Kerekes, J.). OECD, Paris, 164p.

PACE, M. L., 1984, Zooplankton community structure, but not biomass, influence the phosphorus-chlorophyll- $a$ relationship. Can. J. Fish. Aquat. Sci., 41: 1089-1096.

PINTO-COELHO, R. M., 1998, Effects of eutrophication on seasonal patterns of mesozooplankton in a tropical reservoir: a four years study in Pampulha lake, Brazil. Freshwat. Biol., 40: $159-174$.

PINTO-COELHO, R. M. \& GRECO, M. K., 1999, The contribution of water hyacinth (Eichhornia crassipes) and zooplankton to the internal cycling of phosphorus in the eutrophic Pampulha reservoir, Brazil. Hydrobiologia, 411: $115-127$
PINTO-COELHO, R. M. \& ARAUUJO, M. A. R., 1997, Efeitos da remoção de macrófitas sobre a disponibilidade de nitrato e amônia e o zooplâncton de um reservatório eutrófico raso. Anais do VIII Seminário Regional de Ecologia. PPRN UFSCAR, 8: 1217-1223.

PINTO-COELHO, R. M., BEZERRA-NETO, J. F., GIANI, A., MORAIS, C. A. \& CARVALHO, E. A., 2005, The nutritional status of zooplankton in a tropical reservoir: food quality and community structure. Braz. J. Biol., 65(2): 1-13.

PINTO-COELHO, R. M., BEZERRA-NETO, J. F., GIANI, A., MACEDO, C. F., FIGUEREDO, C. C. \& CARVALHO, E. A., 2003, The collapse of a Daphnia laevis (Birge, 1878) population in Pampulha reservoir, Brazil. Acta Limnol. Brasil, 15(3): 53-70.

PRAIRIE, Y. T., DUARTE, C. M. \& KALFF, J., 1989, Unifying nutrient-chlorophyll relationships in lakes. Can. J. Fish. Aquat. Sci., 46: 1176-1182.

ROSEN, R. A., 1981, Length-dry weight relationships of some freshwater zooplankton. J. Freshwat. Ecol., 1: 225-227.

SAKAMOTO, M., 1966, Primary production by phytoplankton community in some Japanese lakes and its dependence on lake depth. Arch. Hydrobiol., 62: 1-28.

SAMPAIO, E. V., ROCHA, O., MATSUMURA-TUNDISI, T. \& TUNDISI, J. G., 2002, Composition and abundance of zooplankton in the limnetic zone of seven reservoirs of the Paranapanema river, Brazil. Braz. J. Biol., 62: 525-545.

SENDACZ, S., 1984, A study of the zooplankton community of Billings reservoir, São Paulo. Hydrobiologia, 113: 121-127.

SENDACZ, S. \& Kubo, E., 1999, Zooplâncton de reservatórios do Alto do Tietê, Estado de São Paulo, pp. 509-530. In: R. Henry (ed.), Ecologia de reservatórios: estrutura, função e aspectos sociais. Fundibio: Fapesp, São Paulo, 800p.

SIEBURTH, J. M., SMETACEK, V. \& LENZ, J., 1978, Pelagic ecosystem structure - heterotrophic compartments of plankton and their relationship to plankton size fractions - comment. Limnol. Oceanogr, 23: 1256-1263.

STARLING, F. L. R. M., 2000, Comparative study of the zooplankton composition of six lacustrine ecosystems in Central Brazil during the dry season. Rev. Bras. Biol., 60: 101-111.

STEMBERGER, R. S. \& LAZORCHAK, J. M., 1994, Zooplankton assemblages responses to disturbance gradients. Can. J. Fish. Aquat. Sci., 51: 2435-2447.

TORRES, I. C., ARAÚJO, M. A. \& PINTO-COELHO, R. M., 1998, Variação sazonal e diurna do carbono orgânico particulado no reservatório da Pampulha, Belo Horizonte, MG. Rev. Bras. Biol., 58: 131-141.

TORRES, I. C. \& PINTO-COELHO, R. M. (submitted). Are tropical reservoirs sinks for essential nutrients? Estimating the mass balance of nitrogen, carbon, phosphorus and suspended solids in an urban and eutrophic Pampulha reservoir, Brazil.

WATSON, S., MCCAULEY, E. \& DOWNING, J. A., 1992, Sigmoid relationships between phosphorus, algal biomass, and algal community structure. Can. J. Fish. Aquat. Sci., 49: 26052610.

VOLLENWEIDER, R. A., 1976, Advances in defining critical loading levels for phosphorus in lake eutrophication. Mem. Ist. Ital. Idrobiol., 33: 53-83. 